\title{
Sub-Acute Toxicity of Pigment Derived from Penicillium resticulosum in Mice
}

\author{
TATANG SOPANDI ${ }^{1} *$ AND WARDAH ${ }^{2}$ \\ ${ }^{\prime}$ Department of Biology, Faculty of Mathematics and Natural Science. Universitas PGRI Adi Buana Surabaya, \\ Jalan Dukuh Menanggal XII, Surabaya 60234, Indonesia; \\ ${ }^{2}$ Department of Food Technology, Faculty of Food Industry, Universitas 17 Agustus 1945 Surabaya, \\ Jalan Semolowaru 45, Surabaya 60234, Indonesia
}

Pigments derived from Penicillium have different toxicities depending on the pigment components. This study was intended to evaluate the sub-acute toxicity of oral exposure of Balb/c mice to Penicillium resticulosum pigment. A total of 50 healthy adult male and female mice were divided into 5 treatment groups and different doses of pigment $\left(0,125,250,500\right.$ and $1000 \mathrm{mg} \mathrm{kg}^{-1}$ body weight) were orally administered. Oral feeding of pigment with doses 125 to $1000 \mathrm{mg} \mathrm{kg}^{-1}$ body weight daily to adult mice did not cause mortality nor any clinical abnormalities. There were no significant differences in body, liver and kidney weights, nor liver and kidney functions of mice when pigment was given orally with intake doses of 125 to $1000 \mathrm{mg} \mathrm{kg}^{-1}$ body weight daily for $28 \mathrm{~d}$ in comparison to mice without pigment intake (control groups). There was a slight difference in liver histopathology of mice exposed to 500 and $1000 \mathrm{mg} \mathrm{kg}^{-1}$ body weight of pigment for $28 \mathrm{~d}$ in comparison to mice control groups, although there were no differences in kidney histopathology. Thus, we can conclude that the pigment of $P$. resticulosum can be cathegorized as low toxic pigment and well tolerated at dose below $500 \mathrm{mg} \mathrm{kg}^{-1}$ body weight daily for $28 \mathrm{~d}$.

Key words: mice, Penicillium, pigment, toxicity

Pigmen yang berasal dari kapang Penicillium diketahui mempunyai toksisitas yang berbeda tergantung pada komponen yang dihasilkan. Penelitian ini bertujuan untuk mengevaluasi toksisitas sub-akut secara oral pigmen dari Penicillium resticulosum pada mencit Balb/c. Sebanyak 50 ekor mencit jantan dan betina dewasa sehat dibagi menjadi 5 kelompok perlakuan masing-masing 5, dan pada masing-masing kelompok diberi pigmen secara oral dengan dosis yang berbeda yaitu diberi $0,125,250,500$, dan $1000 \mathrm{mg} \mathrm{kg}^{-1}$ bobot badan per hari selama 28 hari. Mencit yang diberi pigmen $125-1000 \mathrm{mg} \mathrm{kg}^{-1}$ bobot badan tidak menunjukkan adanya kematian dan kelainan klinis. Fungsi hati dan ginjal mencit yang diberi asupan pigmen $125-1000 \mathrm{mg} \mathrm{kg}^{-1}$ bobot badan setiap hari selama 28 hari tidak berbeda signifikan dibandingkan dengan mencit yang tidak diberi asupan pigmen (control). Terdapat sedikit perubahan profil histologi hati mencit yang diberi asupan pigmen dengan dosis 500 dan $1000 \mathrm{mg} \mathrm{kg}^{-1}$ bobot badan setiap hari selama 28 hari dibandingkan profil histologi hati mencit yang tidak diberi asupan pigmen namun tidak terdapat perbedaan profil histology ginjal mencit pada semua dosis asupan pigmen dibandingkan dengan kontrol. Dapat disimpulkan bahwa pigmen dari P. resticulosum termasuk kategori toksik rendah dan aman dikonsumsi di bawah dosis $500 \mathrm{mg} \mathrm{kg}^{-1}$ bobot badan setiap hari selama 28 hari

Kata kunci : mencit, Penicillium, pigmen, toksisitas

The use of synthetic pigments as dyes has an important role in the food industry (Himri et al. 2011). However, since consumption of food containing certain synthetic pigment is known to cause health problems (Duran et al. 2002; Babitha et al. 2006), public attention towards the development of pigment from materials of natural origin has been increasing (Aberoumand 2011). As manufacturers demand rises for naturally-derived ingredients, particularly in food applications, naturally derived colorants appear set to overtake synthetic colorants in market value (Mapari et al. 2009). It is predicted that naturally derived pigment will have a bright future with a predicted annual growth rate of $5-10 \%$ while synthetic dye color are forecasted to grow at a lower rate of between 3 and 5\% (Downham

*Corresponding author, Phone: +62-81231681744, Fax:+62-31-5042804, E-mail: tatang-sopandi@yahoo.co.id and Collins 2000).

There have been searches to find new sources of natural pigments from plants and animals to replace the synthetic pigment. Microorganisms have lately been receiving more attention as sources of natural pigment (Mapari et al. 2005). Production of pigments by fermentation has a number advantages; possibly easier extraction, higher yields, no lack of raw materials, no seasonal and agroclimate variations, and can be produced in a short period of time (Mortensen 2006; Aberounmand 2011; Poorniammal et al. 2011).

Microorganisms are known to produce various types of polyketide pigments, such as carotenoids, fenazine, acilphenol, pyrone, sclertiorine, and anthraquinone. Only carotenoid pigments and polyketide are known to be toxic (Poorniammal et al. 2011). Meanwhile, various species of fungi found in nature have reported but only a few have been explored 
for the purpose of production of food dyes (Mapari et al.2006).

Production of pigment by the genus Penicillium is more efficient and profitable than the production of pigment by bacteria and yeasts. Penicillium can secrete enzymes and pigments out of the cell. The secreted pigment is relatively stable, thus easily purified. Penicillium can also grow on a variety of lignocellulosic materials. In previous studies, a Penicillium indigenous pigment producer was obtained from soil of Baluran National Park Indonesia and tentatively identified as Penicillium resticulosum based on morphological characteristics. However, the toxicity of pigment from this fungus is not yet known. This study aims to evaluate the sub-acute toxicity of pigment produced by $P$. resticulosum in mice.

\section{MATERIALS AND METHODS}

\section{Fermentation and Pigment Production.} Penicillium sp. was obtained from the laboratory of microbiology collection, Faculty of Mathematics and Natural Sciences, The Universitas of PGRI Adi Buana Surabaya Indonesia. Pigment production by $P$. resticulosum performed on liquid fermentation using a

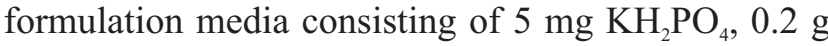
$\mathrm{MgSO}_{4} \cdot \mathrm{H}_{2} \mathrm{O}, 3.0 \mathrm{~g} \mathrm{NaNO}_{3}, 4.0 \mathrm{~g}$ of $\mathrm{NH}_{4} \mathrm{NO}_{3}, 3.0 \mathrm{~g}$ yeast extract, and $30.0 \mathrm{~g}$ carboxymethylcellulose (CMC) in $1000 \mathrm{~mL}$ of hydrolysed corn cob medium with initial $\mathrm{pH}$ of 5.5. Medium was placed in Erlenmeyer flask, homogenized and sterilized in an autoclave at temperatures $121{ }^{\circ} \mathrm{C}$ for $15 \mathrm{~min}$, then cooled to room temperature. All flasks were inoculated with $10 \mathrm{~mL}$ of the spore suspension containing $10^{6}$ cells $\mathrm{mL}^{-1}$ conidia of $P$. resticulosum (estimated based on haemocytometer count). Fermentation was carried out in batch condition at $28-29{ }^{\circ} \mathrm{C}, 50 \%$ relative humidity with $60 \mathrm{rpm}$ agitation for 12 days under dark condition. After incubated, whole of fermented matter was mixed with $200 \mathrm{~mL}$ distilled water and filtered through Whatmann No. 1. Filter followed by centrifugation at $3000 \times \mathrm{g}$ (Hettich EBA 8S Germany) for $15 \mathrm{~min}$ to separate pigment from spore and other material. One liter ethyl acetate was added to an equal volume of supernatant pigment and the mixture was adjusted to $\mathrm{pH} 3.0$ with $2 \mathrm{~N} \mathrm{HCl}$ with vigorous hand mixing and then let to stand for $15 \mathrm{~min}$ until two layers were formed. The ethyl acetate layer (upper layer) was obtained by pipette and evaporated using a rotary vacuum (Heidolph VV2011, Germany) at $50{ }^{\circ} \mathrm{C}$. The pigment was collected and dried to constant weight at $50^{\circ} \mathrm{C}$ for $48 \mathrm{~h}$.

Experiments on Animals and Pigment Administration. A total of 50 healthy male and female $\mathrm{Balb} / \mathrm{c}$ mice aged 3 months, weighing 30-35 g were obtained from PUSVETMA Surabaya and used for 28days sub-acute toxicity evaluation. The mice were acclimatized for 14 days and assigned to five groups each consisting of five males and five females. The mice were housed in polypropylene cages $(5$ mice in one cage) on soft chip bedding, changed twice per week in a controlled room with a 12 hours light-dark cycle and temperature $26 \pm 2{ }^{\circ} \mathrm{C}$ with relative humidity of $55 \%$. They were kept with free access to water and dry commercial pellets feeding. Pigment $P$. resticulosum was fed by oral doses 0 (control), 125, 250, 500, and $1000 \mathrm{mg} \mathrm{kg}^{-1}$ body weight daily in $\mathrm{NaCMC}$ (sodium carboxymethylcellulose) daily for $28 \mathrm{~d}$. Prior to dosing, animals were fasted overnight. Animals were observed thoroughly for onset of any immediate toxic signs and also during observation period of one week. General behaviors observed for the first $1 \mathrm{~h}, 24 \mathrm{~h}$, and one week of test pigment administration were motor activity, tremors, convulsions, straub reaction, aggressiveness, pilo-erection, loss of lighting reflex, sedation, muscle relaxation, hypnosis, analgesia, ptosis, lacrimation, diarrhea and skin colour. At the end of the study ( $28 \mathrm{~d})$, all animals were measured for the following variables; body, liver and kidney weight, aspartate aminotransferase (AST), alanine aminotransferase (ALT), alkaline phosphatase (ALP), lactate dehydrogenase (LDH), blood urea nitrogen (BUN), and liver and kidney histopathology.

Blood Sampling. Blood sampling was done by the cardiac puncture after the mice were anaesthetized by chloroform. Blood samples from each mouse were collected in tubes containing EDTA. Blood samples were stored for 1 hour and centrifuged in the cold at $2500 \mathrm{x}$ g for $10 \mathrm{~min}$. Serum was separated and placed in sterile plastic vials stored at $-20^{\circ} \mathrm{C}$ until use.

Biochemical Studies. Activity of serum Aspartate aminotransferase (AST) and Alanine aminotransferase (ALT) were determined by kinetic method (Teco Diagnostics). Blood urea nitrogen (BUN) was determined by Enzymatic Colorimetric method (Chronolab Cat. No. 101-0248). Alkaline Phosphatase (ALP) was determined by kinetic method (Diachem Ltd Cat. No. 48263). Lactate dehydrogenase (LDH) was determined by modification of Scandinavian Comitee on Enzymes (Chemhouse Cat. No. 065-0150).

Histophatological Studies. After $28 \mathrm{~d}$ pigment treatment, mice were anesthetized with chloroform and 
sacrificed. Liver and kidneys were removed from abdominal cavity and weighed. Liver and renal samples of the control and treated mice were fixed in $10 \%$ phosphate buffered formalin for $24 \mathrm{~h}$ and then the samples were dehydrated and embedded in paraffin. Sections of $5 \mu \mathrm{m}$ were done and stained with hematoxylin and eosin stains for histopathological studies under a bright field microscope with a magnification 400 times. A semi-quantitative analysis was done to assess the extent of the histopathological changes (Wang et al. 2000).

Statistical Analysis. The statistical significance of the differences between control and experimental groups was evaluated by Student's t-test using Statistical Package for the Social Sciences 13.0 (SPSS 13.0) software.

\section{RESULTS}

Mortality, Clinical Signs, Body and Organ Weights. There was no difference found in the mortality and clinical abnormalities in mice treated $P$. resticulosum pigment in comparison to control group (Table 1). However, we found one aggressive male mouse in the group that was given a dose $1000 \mathrm{mg} \mathrm{kg}^{-1}$ body weight $P$. resticulosum pigment daily. Absolute body, liver, and kidney weight in both male and female mice fed $P$. resticulosum pigment did not differ significantly $(\mathrm{P}>0.05)$ in comparison to control group mice. There were no significant $(\mathrm{P}>0.05)$ difference in the ratios of liver to body weight and kidney to body weight in comparison to control group mice (Table 2).

Biochemical Studies. There was no significant difference $(\mathrm{P}>0.05)$ in the level of AST, ALT, ALP, LDH and BUN in both male and female mice (Table 3 ).

Histopathological Liver and Kidney. There were no specific abnormalities of liver histopathology profile in the mice treated with $P$. resticulosum pigment (125 and $250 \mathrm{mg} \mathrm{kg}^{-1}$ body weight daily) for $28 \mathrm{~d}$ in comparison to that of the control group (Fig 1). Very mild sinusoidal congestion was found around the vascular central vein as a response to chloroform anesthesia. The lobular and sinusoids appeared normal and no congestion of sinusoids was seen at liver of mice treated with doses 0 (Fig 1A), 125 (Fig 1B), and 250 (Fig 1C) $\mathrm{mg} \mathrm{kg}^{-1}$ body weight $P$. resticulosum pigment, but fat degeneration and necrosis in some lobus were found in the liver of mice treated with 500 (Fig 1D) and 1000 (Fig 1E) $\mathrm{mg} \mathrm{kg}^{-1}$ body weight $P$. resticulosum pigment daily for $28 \mathrm{~d}$.

Observations (Fig 2) of the pigment effects on kidney histology of mice showed that there was no found abnormal glomerulus, tubular necrosis, and atrophy in the kidneys of mice treated dose 0 (Fig 2A), 125 (Fig 2B), 250 (Fig 2C), 500 (Fig 2D), and 1000 (Fig $2 \mathrm{E}$ ) $\mathrm{mg} \mathrm{kg}^{-1}$ body weight $P$. resticulosum pigment for $28 \mathrm{~d}$.

Table 1 Mortality and clinical signs of Balb Mice/c treated with oral administration of P. resticulosum pigment for one week

\begin{tabular}{|c|c|c|c|c|c|c|c|c|c|c|}
\hline \multirow{3}{*}{ Clinical sign } & \multicolumn{10}{|c|}{ P. resticulosum pigment dose ( $\mathrm{mg} \mathrm{kg}^{-1}$ body weight daily) } \\
\hline & \multicolumn{2}{|c|}{0 (control) } & \multicolumn{2}{|c|}{125} & \multicolumn{2}{|c|}{250} & \multicolumn{2}{|c|}{500} & \multicolumn{2}{|c|}{1000} \\
\hline & M & $\mathrm{F}$ & M & $\mathrm{F}$ & M & $\mathrm{F}$ & M & $\mathrm{F}$ & M & $\mathrm{F}$ \\
\hline Mortality & $0 / 5$ & $0 / 5$ & $0 / 5$ & $0 / 5$ & $0 / 5$ & $0 / 5$ & $0 / 5$ & $0 / 5$ & $0 / 5$ & $0 / 5$ \\
\hline Motor activity & $0 / 5$ & $0 / 5$ & $0 / 5$ & $0 / 5$ & $0 / 5$ & $0 / 5$ & $0 / 5$ & $0 / 5$ & $0 / 5$ & $0 / 5$ \\
\hline Tremors & $0 / 5$ & $0 / 5$ & $0 / 5$ & $0 / 5$ & $0 / 5$ & $0 / 5$ & $0 / 5$ & $0 / 5$ & $0 / 5$ & $0 / 5$ \\
\hline Convulsions & $0 / 5$ & $0 / 5$ & $0 / 5$ & $0 / 5$ & $0 / 5$ & $0 / 5$ & $0 / 5$ & $0 / 5$ & $0 / 5$ & $0 / 5$ \\
\hline Straub reaction & $0 / 5$ & $0 / 5$ & $0 / 5$ & $0 / 5$ & $0 / 5$ & $0 / 5$ & $0 / 5$ & $0 / 5$ & $0 / 5$ & $0 / 5$ \\
\hline Aggressiveness & $0 / 5$ & $0 / 5$ & $0 / 5$ & $0 / 5$ & $0 / 5$ & $0 / 5$ & $0 / 5$ & $0 / 5$ & $1 / 5$ & $0 / 5$ \\
\hline Pilo-erection & $0 / 5$ & $0 / 5$ & $0 / 5$ & $0 / 5$ & $0 / 5$ & $0 / 5$ & $0 / 5$ & $0 / 5$ & $0 / 5$ & $0 / 5$ \\
\hline Loss of lighting reflex & $0 / 5$ & $0 / 5$ & $0 / 5$ & $0 / 5$ & $0 / 5$ & $0 / 5$ & $0 / 5$ & $0 / 5$ & $0 / 5$ & $0 / 5$ \\
\hline Sedation & $0 / 5$ & $0 / 5$ & $0 / 5$ & $0 / 5$ & $0 / 5$ & $0 / 5$ & $0 / 5$ & $0 / 5$ & $0 / 5$ & $0 / 5$ \\
\hline Muscle relaxation & $0 / 5$ & $0 / 5$ & $0 / 5$ & $0 / 5$ & $0 / 5$ & $0 / 5$ & $0 / 5$ & $0 / 5$ & $0 / 5$ & $0 / 5$ \\
\hline Hypn osis & $0 / 5$ & $0 / 5$ & $0 / 5$ & $0 / 5$ & $0 / 5$ & $0 / 5$ & $0 / 5$ & $0 / 5$ & $0 / 5$ & $0 / 5$ \\
\hline Analgesia & $0 / 5$ & $0 / 5$ & $0 / 5$ & $0 / 5$ & $0 / 5$ & $0 / 5$ & $0 / 5$ & $0 / 5$ & $0 / 5$ & $0 / 5$ \\
\hline Ptosis & $0 / 5$ & $0 / 5$ & $0 / 5$ & $0 / 5$ & $0 / 5$ & $0 / 5$ & $0 / 5$ & $0 / 5$ & $0 / 5$ & $0 / 5$ \\
\hline Lacrimation & $0 / 5$ & $0 / 5$ & $0 / 5$ & $0 / 5$ & $0 / 5$ & $0 / 5$ & $0 / 5$ & $0 / 5$ & $0 / 5$ & $0 / 5$ \\
\hline Diarrhea & $0 / 5$ & $0 / 5$ & $0 / 5$ & $0 / 5$ & $0 / 5$ & $0 / 5$ & $0 / 5$ & $0 / 5$ & $0 / 5$ & $0 / 5$ \\
\hline Skin color & $0 / 5$ & $0 / 5$ & $0 / 5$ & $0 / 5$ & $0 / 5$ & $0 / 5$ & $0 / 5$ & $0 / 5$ & $0 / 5$ & $0 / 5$ \\
\hline
\end{tabular}

M: male of five measurements; F: female of five measurements 
Table 2 Effect of oral administration of $P$. resticulosum pigment on body, liver, and kidney weight of mice

\begin{tabular}{|c|c|c|c|c|c|}
\hline & \multicolumn{5}{|c|}{ P. resticulosum pigment dose ( $\mathrm{mg} \mathrm{kg}^{-1}$ body weight daily) } \\
\hline & 0 (control) & 125 & 250 & 500 & 1000 \\
\hline \multicolumn{6}{|c|}{ Absolute Body Weight (g) } \\
\hline Prior treatment & & & & & N.D. \\
\hline Male & $29.18 \pm 2.36$ & $31.64 \pm 3.63$ & $30.98 \pm 0.97$ & $30.42 \pm 2.36$ & $27.86 \pm 3.63$ \\
\hline Female & $26.20 \pm 1.30$ & $27.20 \pm 1.92$ & $27.40 \pm 1.14$ & $26.01 \pm 1.58$ & $26.80 \pm 3.63$ \\
\hline \multicolumn{6}{|l|}{ On day 28} \\
\hline Male & $29.38 \pm 2.32$ & $31.78 \pm 3.63$ & $31.10 \pm 0.83$ & $30.66 \pm 2.31$ & $28.46 \pm 3.22$ \\
\hline Female & $26.40 \pm 1.34$ & $27.46 \pm 1.84$ & $27.66 \pm 1.12$ & $26.32 \pm 1.51$ & $27.06 \pm 0.83$ \\
\hline \multicolumn{6}{|l|}{ Liver } \\
\hline Male & $1.37 \pm 0.054$ & $1.41 \pm 0.084$ & $1.40 \pm 0.021$ & $1.40 \pm 0.058$ & $1.35 \pm 0.075$ \\
\hline Female & $1.30 \pm 0.019$ & $1.33 \pm 0.054$ & $1.32 \pm 0.045$ & $1.29 \pm 0.022$ & $1.28 \pm 0.027$ \\
\hline \multicolumn{6}{|l|}{ Kidney } \\
\hline Male & $0.51 \pm 0.046$ & $0.52 \pm 0.059$ & $0.51 \pm 0.016$ & $0.51 \pm 0.027$ & $0.51 \pm 0.066$ \\
\hline Female & $0.44 \pm 0.005$ & $0.47 \pm 0.014$ & $0.44 \pm 0.010$ & $0.44 \pm 0.014$ & $044 \pm 0.007$ \\
\hline \multicolumn{6}{|c|}{ Relative (\% g animal $\left.{ }^{-1}\right)$} \\
\hline \multicolumn{6}{|l|}{ Liver } \\
\hline Male & $4.72 \pm 0.22$ & $4.49 \pm 0.25$ & $4.53 \pm 0.12$ & $4.61 \pm 0.18$ & $4.89 \pm 0.40$ \\
\hline Female & $4.97 \pm 0.19$ & $4.88 \pm 0.18$ & $4.83 \pm 0.09$ & $4.97 \pm 0.23$ & $4.79 \pm 0.09$ \\
\hline \multicolumn{6}{|l|}{ Kidney } \\
\hline Male & $1.74 \pm 0.04$ & $1.64 \pm 0.02$ & $1.65 \pm 0.09$ & $1.66 \pm 0.06$ & $1.71 \pm 0.02$ \\
\hline Female & $1.75 \pm 0.13$ & $1.70 \pm 0.07$ & $1.70 \pm 0.08$ & $1.77 \pm 0.12$ & $1.67 \pm 0.02$ \\
\hline
\end{tabular}

Values represent the mean \pm SD of five measurements, $\mathrm{P}<0.05$ indicates significant difference from controls.

N.D.: not detected

Table 3 Effect of $P$. resticulosum pigment administration on biochemical parameters of mice

\begin{tabular}{|c|c|c|c|c|c|}
\hline \multirow{2}{*}{ Parameters } & \multicolumn{5}{|c|}{ P. resticulosum pigment dose ( $\mathrm{mg} \mathrm{kg}^{-1}$ body weight daily) } \\
\hline & 0 (control) & 125 & 250 & 500 & 1000 \\
\hline \multicolumn{6}{|l|}{$\operatorname{AST}\left(\mathrm{UL}^{-1}\right)$} \\
\hline Male & $76.02 \pm 0.75$ & $76.04 \pm 1.11$ & $76.70 \pm 1.27$ & $77.01 \pm 1.27$ & $77.84 \pm 0.72$ \\
\hline Female & $83.62 \pm 1.33$ & $84.19 \pm 0.88$ & $84.74 \pm 1.50$ & $85.86 \pm 1.38$ & $85.96 \pm 2.08$ \\
\hline \multicolumn{6}{|l|}{$\operatorname{ALT}\left(\mathrm{UL}^{-1}\right)$} \\
\hline Male & $75.15 \pm 0.81$ & $74.97 \pm 0.52$ & $75.80 \pm 1.13$ & $75.73 \pm 0.92$ & $76.40 \pm 1.09$ \\
\hline Female & $74.63 \pm 1.31$ & $75.18 \pm 0.97$ & $75.52 \pm 1.68$ & $75.54 \pm 0.76$ & $76.35 \pm 118$ \\
\hline \multicolumn{6}{|l|}{$\operatorname{ALP}\left(\mathrm{UL}^{-1}\right)$} \\
\hline Male & $38.30 \pm 1.80$ & $38.81 \pm 2.35$ & $40.72 \pm 1.31$ & $40.16 \pm 0.95$ & $40.42 \pm 0.69$ \\
\hline Female & $34.70 \pm 1.45$ & $34.81 \pm 2.19$ & $36.52 \pm 1.03$ & $36.56 \pm 0.95$ & $37.02 \pm 1.23$ \\
\hline \multicolumn{6}{|l|}{$\mathrm{LDH}\left(\mathrm{UL}^{-1}\right)$} \\
\hline Male & $1288.47 \pm 67.62$ & $1342.59 \pm 54.31$ & $1348.74 \pm 30.23$ & $1351.77 \pm 45.82$ & $1367.54 \pm 28.80$ \\
\hline Famale & $1199.51 \pm 72.58$ & $1249.64 \pm 55.64$ & $1269.86 \pm 39.88$ & $1280.03 \pm 36.71$ & $1263.79 \pm 47.33$ \\
\hline \multicolumn{6}{|c|}{ BUN (mg dL $\left.{ }^{-1}\right)$} \\
\hline Male & $16.26 \pm 3.32$ & $15.94 \pm 3.35$ & $16.06 \pm 3.60$ & $17.94 \pm 3.01$ & $15.90 \pm 3.07$ \\
\hline Female & $16.90 \pm 2.38$ & $18.28 \pm 1.12$ & $16.68 \pm 2.40$ & $18.10 \pm 1.26$ & $18.14 \pm 1.55$ \\
\hline
\end{tabular}

Values represent the mean $\pm \mathrm{SD}$ of five measurements, $\mathrm{P}<0.05$ indicates significant difference from controls.

\section{DISCUSSION}

Evaluation of oral toxicity using $28 \mathrm{~d}$ toxicity tests generally has been conducted in sub-acute toxicity study which is the fundamental test to determine the level of product safety(Arts et al., 2004: Wang et al. 2007; Poorniammal et al. 2011 ), including the safety of food coloring pigments produced by microorganisms 

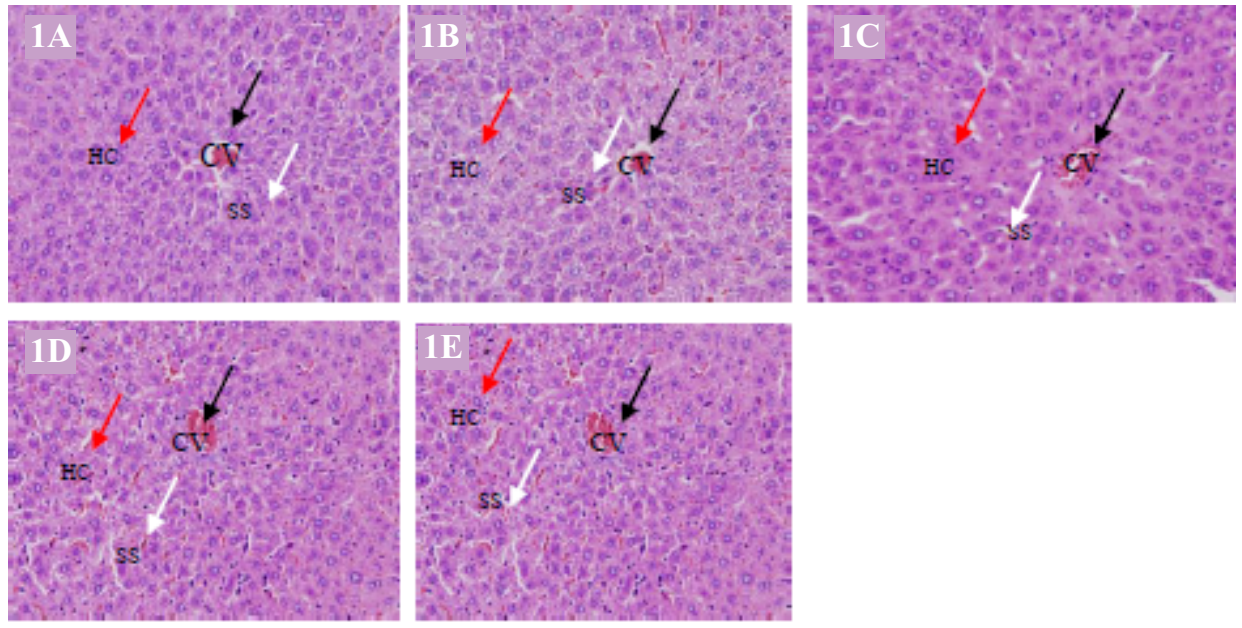

Fig 1 Liver section (magnification $400 \mathrm{x}$ ) of mice treated with orally administered various doses of $P$. resticulosum pigment: 0 (A), 125 (B), 250 (C), 500 (D), and 1000 (E) $\mathrm{mg} \mathrm{kg}^{-1}$ body weight daily for $28 \mathrm{~d}$. Vena centralis (CV) marked with black arrows, hepatocyte cell (HC) marked with red arrow, and sinusoids (SS) marked with white arrows.
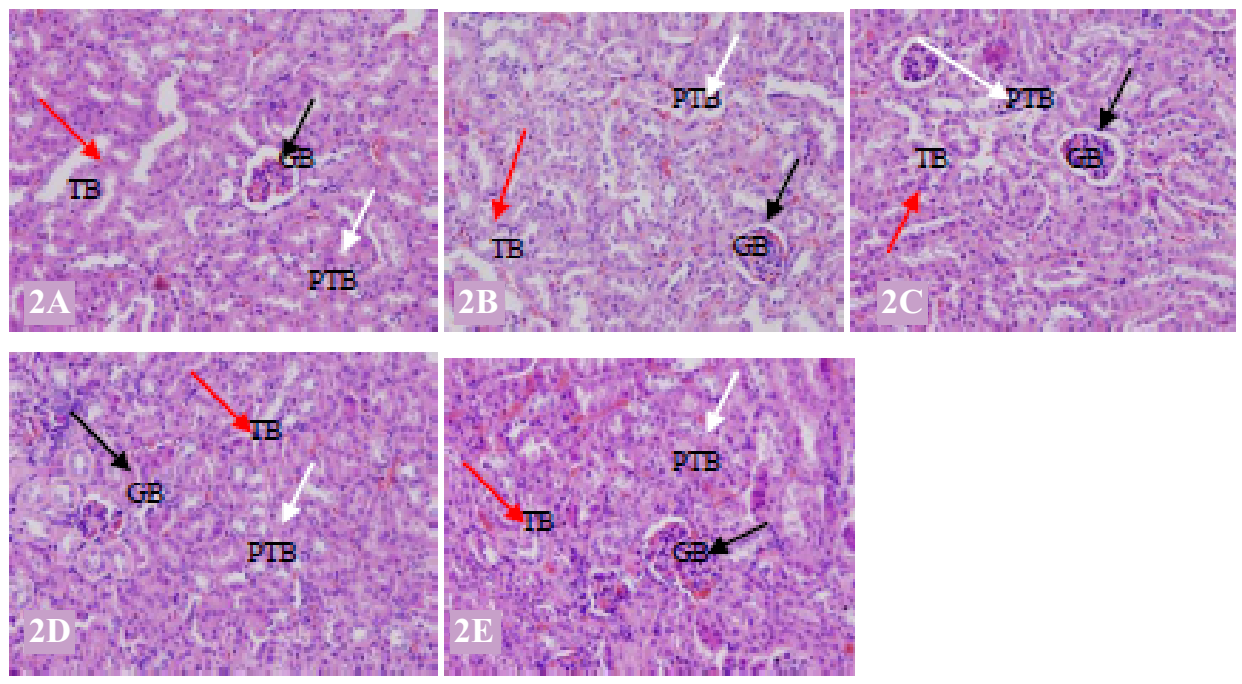

Fig 2 Kidney section (magnification $400 \mathrm{x}$ ) of mice treated with orally administered various doses $P$. resticulosum pigment: 0 (A), 125 (B), 250 (C), 500 (D) and 1000 (E) $\mathrm{mg} \mathrm{kg}^{-1}$ body weight per day for 28 days. Glomeruli (GB) marked with black arrows, tubules (TB) marked red arrows, and proximal tubules (PTB) marked with white arrows.

(Kumari et al. 2009). In this study, during the administration period, no death occurred in animals from any group. There were no abnormal signs in the groups. Pigments from Penicillium have varied toxicity depending on the comonents of the pigment. Pigment omponent such as atrovenetin and norherqueinone from P. antrovenetum (Raistrick et al. 1958), antrovenetin and herquinones from $P$. herquei (Robinson et al. 1992), anthraquinone from P. citrinum (Duran et al. 2002), phoenicin from $P$. antrosanguineum, xanthoepocin from $P$. brevicompactum, anthraquinone derivatives arpink red from P. oxalicum (Mapari et al. 2005), mitosrubin, mitosrubinol and purpurogenone from $P$. purpurogenum (Mapari et al. 2006) have been known as non-toxic pigment. On the other hand, toxic pigment components include citrinine from P. citrinum (Duran et al. 2002), and acid-secalonic D from P. oxalicum (Mapari et al. 2005). Toxicity of pigment produced by $P$. resticulosum has not been reported by previous investigators. Shridhar et al. (2009) reported that the culture filtrate of $P$. resticulosum did not contain mycotoxins and $1.5 \mathrm{~mL}$ of culture filtrate of $P$. resticulosum only causes the death of mice after administration of the filtrate for $45 \mathrm{~d}$.

Body and organ weights and ratio of organ with body weight are indicators of organ damages or abnormalities due to provision of treatment (Poorniammal et al. 2011). This study indicates that the administration of $P$. resticulosum pigment for $28 \mathrm{~d}$ produced no effect on the body weight gain and abnormalities in liver and kidney of mice. Shridhar et al. (2009) reported that although the administration of 
$1.5 \mathrm{~mL}$ of culture filtrate of $P$. resticulosum gave no effect on the body weight of mice, the body weight decreased gradually until the provision of $45 \mathrm{~d}$.

Activities of AST, ALT, ALP, and LDH are indicators of liver damage. Our study demonstrated that the daily intake of $P$. resticulosum pigment for 28 day exhibited no significant effect on AST, ALT, ALP, and LDH when compared to the both male and female control mouse. The culture filtrate of $P$. resticulosum with a dose of $1.5 \mathrm{~mL}$ per day for $45 \mathrm{~d}$ can increase the concentration of AST and ALT enzymes, indicating liver damage (Shridhar et al. 2009). Fumaryl-dlalanine (Fumaromono-dl-alanine) is a metabolic product of $P$. resticulosum that might have caused altered permeability and/ cell necrosis, leaked of the enzymes into the bloodstream (Birkinshaw et al 1942).

Consumption of synthetic or natural food colorant after 30 days of treatment increased serum creatinine and urea in rats (Helal et al. 2000; Himri et al. 2011). Blood urea nitrogen is an indicator of kidney damage as a result of enzymatic hydrolysis of urea by urease to ammonia (Zafar et al. 2010). Our study showed upon the administration $P$. resticulosum pigment in mice for 28 days there were no differences in BUN levels in both male and female mice compared to mice control groups.

Loss of the structure and abnormal function of cells are the results fat metabolism disorder in cells, inducing degeneration. Cells undergoing fatty degeneration was characterized by the accumulation of metabolic products such as molecules of fat, protein and glycogen in abnormal amounts. Fatty degeneration of the cells indicates the presence of biochemical disturbances caused by abnormal metabolism. Toxic chemicals that are microscopically visible as grains of fat accumulated in the liver lobes, especially the perilobular tissue. The present study revealed that mouse consuming high dose of $P$. resticulosum pigment (500 and $1000 \mathrm{mg} \mathrm{kg}^{-1}$ body weight) daily for 28 days exhibited slight existence of fatty degeneration and necrosis in some lobus.

Kidney proximal tubule is the most vulnerable to damage from toxic substances. In the proximal tubule occur the process of absorption and secretion of various substances. If there is absorption of toxic materials in the tubular epithelium, it would interfere with the metabolism and absorption. In addition, levels of cytochrome P-450 in the proximal tubule increased to detoxify toxic substances. In the present study, microscopic observations of kidneys histopathologic preparations found no abnormalities in glomeruli, tubules, proximal tubules and capillaries between the tubules.

In conclusion, the $28 \mathrm{~d}$ sub-acute toxicity evaluation indicates that pigments produced by $P$. resticulosum can be categorized as low toxicity pigments. Provision of P. resticulosum pigment up to a dose of $500 \mathrm{mg} \mathrm{kg}^{-1}$ body weight daily for 28 days had no effect on body weight, organ weights, and activities of AST, ALT, ALP, LDH enzymes and BUN. However, mouse taking $P$. resticulosum pigment above $500 \mathrm{mg}$ $\mathrm{kg}^{-1}$ body weight daily showed fatty degeneration and mild necrosis of liver cells indicating that the consumption of pigment from $P$. resticulosum was still safe up to doses below $500 \mathrm{mg} \mathrm{kg}^{-1}$ body weight daily for $28 \mathrm{~d}$.

\section{ACKNOWLEDGMENT}

The authors would like thank to DP2M Higher Education for financial support of the research through Research Grants for Fundamental Research Year 2011.

\section{REFERENCES}

Aberoumand A. 2011. A review on edible pigments properties and sources as natural biocolorants in foodstuff and food industry. World J Dairy Food Sci. 6(1):71-78

Arts JHE, Muijser H, Appel MJ, Kuper CF, Bessems JGM, Woutersen RA. 2004. Sub-acute (28-day) toxicity of furfural in Fischer 344 rats: a comparison of oral and inhalation route. Food Chem Toxicol. 42(9):1389-1399. doi:10.1016/j.fet.2004.03.014.

Babitha S, Soccol CR, Pandey A. 2006. Jackfruit seed- A novel substrate for the production of Monascus pigments through solid-state fermentation. Food Technol Biotechnol. 44(4):465-471.

Downham L, Collins P. 2000. Colouring our foods in the last and nex millenium. Int J Food Sci Technol. 35:5-22.

Birkinshaw JH, Raistrick H, Smith G. 1942. Studies in the biochemistry of micro-organisms; Fumaryl- $d l$-alanine (fumaromono- $d l$-alanide), a metabolic product of Penicillium resticulosum sp.nov. Biochem J. 36(10-12): 829-835.

Duran N, Teixeira MF, De Conti R, Esposito E. 2002. Ecological-friendly pigment from fungi. Crit Rev Food Sci Nutr. 42(1):53-66.

Helal GE, Zaahkouk AM, Mekkawy AH. 2000. Effect of some food colorants (synthetic and natural products) of young albino rats. Egypt J Hosp Med. 200(1):103-113.

Himri I, Bellahcen S, Souna F, Belmekki F, Aziz M, Bnouham M, Zoheir J, Berkia Z, Mekhfi H, Saalaoui E. 2011. A 90-day oral toxicity study of tartrazine, a synthetic food dye, in wistar rats. Int J of Pharm Pharm Sci. 3(3):159-169. 
Kumari HPM, Naidu KA, Vishwanatha S, Narasimhamurthy K, Vijayalakshmi G. 2009. Safety evaluation of Monascus purpureus red mould rice in albino rats. Food Chem Toxicol. 47(8): 1739-1746. doi:10.1016/j.fct. 2009.04.038

Mapari SAS, Nielsen KF, Larson TO, Frisvad JC, Meyer AS, Thrane U. 2005. Exploring fungal biodiversity for production of water soluble pigment as potential natural food colorant. Curr Opin Biotechnol. 16(2):231-238. doi:10.1016/j.copbio.2005.03.004

Mapari SAS, Meyer AS, Thrane U. 2006. Colorimetric characterization for comparative analysis of fungal pigment and natural colorants. J Agric Food Chem. 54(19):7027-7035. doi: 10.1021/jf062094n.

Mapari SAS, Meyer AS, Thrane U, Frisvad JC. 2009. Identification of potentially safe promising fungal cell factories for the production of polyketide natural food colorants using chemotaxonomic rationale. Microb Cell Fact. 8:24:1-15.

Mortensen A. 2006. Carotenoids and other pigments as natural colorants. Pure Appl Chem. 78(8):1477-1491. doi:10.1351/pac200678081477.

Poorniammal R, Gunasekaran S, Ariharasivakumar G. 2011. Toxicity evaluation of fungal food colourant from Thermomyces sp. in albino mice. J Sci and Indus Res. 70(9):773-777.

Raistrick H, Stossl A. 1958. Studies in the biochemistry of microorganisms 104. Metabolites of Penicillium atrovenetum $\mathrm{G}$. Smith $\beta$-nitropropionic acid, a major metabolite. Biochem J. 68:647-653.

Robinson N, Wood K, Hylands PJ, Gibson TM, Weedon CJ, Covill. 1992. Blue pigment of Penicillium herquei. J Nat Prod. 55(6):814-817. doi: 10.1021/np50084a019.

Shridhar NB, Veena K, Suguna R, Jayakumar K. 2009. Subchronic toxicity study of Penicillium resticulosum culture filtrate in mice. J Vet Pharm Toxicol. 8(1-2):6365 .

Wang T, Fonetenot RD, Roni MG, Bucci TJ, Mehendale HM. 2000. Enhanced hepatotoxicity and toxic outcome of thioacetamide in streptozotocin-induced diabetic rat. Toxicol Appl Pharmacol. 166(2):92-100. doi:10.1006/taap.2000.8952.

Wang TC, Su YP, Hsu TY, Yang CC, Lin CC. 2007. 28-day oral toxicity study of the aqueous extract from spider brake (Pteris mulfida Poiret) in rats. Food Chem Toxicol. 45(9):1757-1763. doi:10.1016/j.fct.2007. 03.010 .

Zafar I, Ravichandran K, Belibi FA, Doctor RB, Edelstein CL. 2010. Sirolimus attenuates disease progression in an orthologous mouse model of human autosomal dominant polycystic kidney disease. Kidney Int. 78(2): 754-761. doi:10.1038/ki.2010.250. 